\title{
SISTEM INFORMASI LAYANAN KESEHATAN DENGAN MENGGUNAKAN CODEIGNITER PADA PUSKESMAS BULULAWANG
}

\author{
${ }^{[1]}$ Eka Yuniar, ${ }^{[2]}$ Mochamad Hasanudin Muslim \\ ${ }^{[1]}$ STMIK PPKIA Pradnya Paramita, ${ }^{[2]}$ STMIK PPKIA Pradnya Paramita
}

\begin{abstract}
Abstrak: Penelitian ini bertujuan untuk membuat Sistem Informasi Layanan Kesehatan pada Puskesmas Bululawang dengan menggunakan Codeigneter. Hal ini dikarenakan pada Puskesmas Bululawang belum memiliki sistem yang terintegrasi dalam hal pelayanan administrasi kepada pasien dan pengolahan laporan kepada Dinas yang kurang efektif dan efisien. Pembuatan sistem informasi layanan kesehatan ini dengan menggunakan codeigneter dengan berorientasi dengan objek, sedangkan metode penelitian dengan menggunakan metode prototype. Adapun data yang digunakan dalam penelitian ini adalah data pasien dan data rekam medis pada Puskesmas Bululawang. Adapun pengujian sistem menggunakan metode blacbox dengan menguji fungsionalitas sistem, sedangkan variabel pengujian lain dengan menggunakan pengukuran waktu proses untuk menilai pengukuran metode kerja sistem. Penelitian ini menghasilkan proses pelayanan kesehatan pada Puskesmas lebih cepat sampai dengan 87,5\% untuk proses pendaftaran pasien, 99,7 \% untuk proses pencarian data rekam medis, dan 97,02\% untuk proses pembuatan Laporan Medis.
\end{abstract}

Kata Kunci: Sistem Informasi, Rekam Medis, Codeigniter, Layanan Kesehatan

\section{Pendahuluan}

Pusat kesehatan masyarakat atau yang biasa disingkat dengan Puskesmas merupakan unit layanan kesehatan yang di danai oleh pemerintah dan merupakan unit yang menjadi rujukan masyarakat dalam melakukan pemeriksaan kesehatan. Dengan digalakannya peningkatan pelayanan di setiap puskesmas tentu tingkat kepuasan pasien terhadap pelayanan kesehatan merupakan faktor yang tidak kalah penting yang menjadi perhatian puskesmas dalam memberikan kepercayaan bagi masyarakat terutama dalam program peningkatan derajat kesehatan masyarakat dapat tercapai dengan maksimal. Menurut hasil pengamatan dan wawancara dengan kepala Puskesmas Bululawang dan beberapa pasien, mereka berpendapat bahwa sistem pelayanan kesehatan yang ada saat ini masih memiliki banyak kekurangan, antara lain dari pemberian informasi yang terbatas, daftar tunggu pelayanan yang relatif lama, waktu pelayanan yang bisa memakan waktu hampir 60 menit per kedatangan pasien dan pencatatan riwayat kunjungan pasien yang masih konvensional dengan media tulis sehingga kesulitan dalam mencari riwayat kunjungan pasien yang terdahulu.

Puskesmas Bululawang pada awalnya menggunakan pencatatan manual dalam melayani pasien, pasien yang telah terdaftar diharuskan mengambil nomor antrian untuk antri di loket terlebih dahulu, kemudian dari petugas loket akan mencarikan nomor rekam medis dan kemudian mengisi rekap harian secara manual di buku harian, setelah pasien tersebut telah didaftarkan pada buku rekap harian pasien harus menunggu lagi di panggil oleh poli melalui pengeras suara, dan petugas loket mengantarkan berkas rekam medis ke poli yang dituju, hal ini rawan terjadi kesalahan dikarenakan minimnya petugas loket dan antrian pasien yang ramai karena kunjungan per hari rata-rata hampir 150 pasien dalam semua rawat jalan, setelah dilayani di poliklinik puskesmas pasien harus antri lama karena resep yang diantar oleh dokter dari poliklinik ke apotik yang memakan waktu.

Tidak hanya dari segi pelayanan kepada masyarakat yang mengalami banyak kendala dan kurang maksimal namun dengan sistem pelayanan kesehatan yang masih manual petugas puskesmas 
seringkali mengalami kesulitan dalam melakukan pengolahan data terutama dalam menganalisa data yang diperlukan untuk membuat laporan kesehatan menjadi lebih lama sebab data kunjungan per bulan bisa mencapai lebih dari 2400 data rekam medis baru sementara petugas harus melakukan rekap secara manual dengan waktu antara 7-14 hari, sehingga laporan yang diperlukan mengalami keterlambatan, terutama laporan kepada dinas kabupaten yang berpengaruh dalam pengadaan obat bagi puskesmas.

Salah satu solusi yang ditawarkan dengan pembuatan sistem informasi layanan kesehatan dengan menggunakan Codeigniter hal ini berdasarkan hasil penelitian Syukron (2015) dalam judul Perancangan Sistem Informasi Rawat Jalan Berbasis Web Pada Puskesmas Winong yaitu Aplikasi dapat membantu kinerja dari puskesmas dalam pengolahan data dan pembuatan laporan kesehatan. Selain itu menurut Ernawati (2014) dalam judulnya Pembangunan Sistem Informasi Puskesmas Pembantu Desa Nglaran pembuatan sistem menghasilkan sistem informasi kunjungan puskesmas pembantu desa nglaran yang dapat mempermudah proses pendataan data pengunjung puskesmas.

Berdasarkan latar belakang tersebut maka dibutuhkan untuk membangun Aplikasi Sistem Informasi Layanan Kesehatan Puskesmas Bululawang yang sesuai dengan kebutuhan Puskesmas Bululawang sendiri sehingga diharapkan dapat membantu dalam menyelesaikan masalah yang ada di Puskesmas Bululawang.

\section{A. Pengertian Sistem Informasi}

\section{LANDASAN TEORI}

Sistem informasi mencakup sejumlah komponen (manusia, komputer, teknologi informasi, dan prosedur kerja), ada suatu yang di proses (data menjadi informasi), dan dimaksudkan untuk mencapai suatu sasaran atau tujuan (Kadir, 2014).

Sistem informasi merupakan kumpulan dari komponen-komponen yangmengumpulkan, memproses, menyimpan, dan menyediakan output darisetiap informasi yang dibutuhkan dalam proses bisnis serta aplikasi yang digunakan melalui perangkat lunak, database dan bahkan proses manual yang terkait (Satzinger, 2010).

\section{B. Puskesmas}

Puskesmas merupakan suatu kesatuan organisasi kesehatan fungsional yang merupakan pusat pengembangan kesehatan masyarakat yang juga membina peran serta masyarakat disamping memberikan pelayanan secara menyeluruh dan terpadu kepada masyarakat di wilayah kerjanya dalam bentuk kegiatan pokok.

\section{Rekam Medis}

Menurut PERMENKES No.269/MENKES/PER/III/2008 yang dimaksud rekam medis adalah berkas yang berisi catatan dan dokumen antara lain identitas pasien, hasil pemeriksaan, pengobatan yang telah diberikan, serta tindakan dan pelayanan lain yang telah diberikan kepada pasien.

Dalam penjelasan Pasal 46 ayat (1) UU Praktik Kedokteran, yang dimaksud dengan rekam medis adalah berkas yang berisi catatan dan dokumen tentang identitas pasien, pemeriksaan, pengobatan, tindakan dan pelayanan lain yang telah diberikan kepada pasien.

\section{Codeignniter}

Menurut Hakim (2010) CodeIgniter adalah sebuah framework PHP yang dapat membantu mempercepat developer dalam pengembangan aplikasi web berbasis PHP dibanding jika menulis semua kode program dari awal.

CodeIgniter pertama kali dibuat oleh Rick Ellis, CEO Ellislab, Inc. sebuah perusahaan yang memproduksi CMS (Content Management System) yang cukup handal, yaitu Expression Engine. Saat 
ini, CodeIgniter dikembangkan dan dimaintain oleh Expression Engine Development Team. Adapun beberapa keuntungan menggunakan CodeIgniter, diantaranya:
1. Gratis
: CodeIgniter berlisensi dibawah Apache/BSD opensource.

2. Tulisan PHP 4

: Meskipun CodeIgniter dapat berjalan di PHP 5, namun sampai saat ini kode program CodeIgniter masih dibuat dengan menggunakan PHP 4.

3. Ukuran Kecil

4. Konsep MVC

5. URL Sederhana

6. Paket Library Lengkap

7. Extensible

8. Tidak perlu Template Engine:

9. Dokumentasi Lengkap Jelas :
: Ukuran CodeIgniter yang kecil merupakan keunggulan tersendiri. dibanding dengan framework lain yang berukuran besar.

: CodeIgniter menggunakan konsep MVC yang memungkinkan pemisah layer application-logic dan presentation.

: Secara default, URL yang dihasilkan CodeIgniter sangat bersih dan Search Engine Friendly (SEF).

: CodeIgniter mempunyai library yang lengkap untuk mengerjakan operasi- operasi yang umum dibutuhkan oleh sebuah aplikasi berbasis web, misalnya mengakses database, mengirim email, memvalidasi form, menangani session dan sebagainya.

: Sistem dapat dikembangkan dengan mudah menggunakan plugin dan helper, atau dengan menggunakan hooks.

Meskipun CodeIgniter dilengkapi dengan template parser sederhana yang dapat digunakan, tetapi hal ini tidak mengharuskan kita untuk menggunakannya.

Dari sekian banyak framework, CodeIgniter adalah satu-satunya framework dengan dokumentasi yang lengkap dan jelas.

\section{A. Metode Pengembangan Sistem}

\section{Metode Penelitian}

Menurut Andrianto (2017), metode pengembangan sistem yang digunakan dengan menggunakan metode prototype sebagai metode pengembangan dengan adanya beberapa keunggulan dan sesuai dengan masalah. Berikut proses pembuatan prototype.

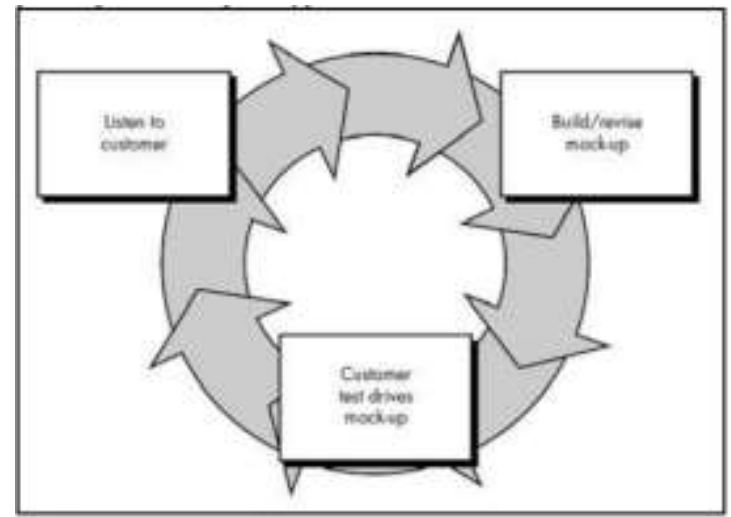

Gambar 1. Prototype Model

\section{Analisa Kebutuhan Sistem}

Proses analisa kebutuhan sistem yang dibutuhkan dilakukan berdasarkan proses pengamatan dari sistem yang sedang berjalan. Berikut ini merupakan hasil dari analisis sistem yang sedang berjalan.

a. Kelemahan sistem pendaftaran 
i) Waktu antrian pendaftaran pasien lama $\pm 40-60$ menit

ii) Pencarian daftar rekam medis pasien $\pm 30-40$ menit

iii) Proses pelaporan medis puskesmas $\pm 7-14$ hari

b. Kebutuhan pemakai sistem

i) Proses pendaftaran pasien dapat dilakukan lebih cepat dan terintegrasi dengan

ii) Pencarian riwayat medis pasien/ rekam medis dapat dilakukan dengan mudah sehingga waktu tunggu dapat berkurang.

iii) Proses pembuatan laporan medis puskesmas kepada Dinas Kesehatan dapat dilakukan secara cepat dan up to date tanpa harus menunggu pembuatan laporan yang memakan waktu berhari-hari.

\section{Desain Sistem}

Penelitian menggunakan Pada penelitian ini menggunakan alat bantu pemodelan visual dengan UML (Unified Modelling Language) sehingga pada sub bab ini dibahas mengenai use case, sequence diagram, class diagram, activity diagram dari sistem yang dibangun, serta desain interface dari sistem.

\section{Pengujian Sistem}

Pengujian sistem dilakukan dengan menggunakan Black Box testing yaitu berfokus pada spesifikasi fungsional dari perangkat lunak. Tester dapat mendefinisikan kumpulan kondisi input dan melakukan pengetesan pada spesifikasi fungsional program. Black Box Testing bukanlah solusi alternatif dari White Box Testing tapi lebih merupakan pelengkap untuk menguji hal-hal yang tidak dicakup oleh White Box Testing. Black Box Testing cenderung untuk menemukan hal-hal berikut: a) Fungsi yang tidak benar atau tidak ada. b) Kesalahan Black Box Testing antarmuka (interface errors). c) Kesalahan pada struktur data dan akses basis data. d) Kesalahan performansi (performance errors). e) Kesalahan inisialisasi dan terminasi.

\section{Implementasi}

Setelah tahap pengujian selesai maka proses selanjutnya adalah proses implementasi. Pada tahap ini yaitu mempersiapkan spesifikasi hardware dan software yang nantinya dapat digunakan untuk pengoperasian sistem antara lain sebagai berikut.

\section{a) Konfigurasi Hardware}

i) Processor minimum berbasis Dual Core

ii) Memory minimum $2 \mathrm{gb}$ lebih sesuai dengan pemakaian atau lebih

iii) Space minimum hardisk $100 \mathrm{~GB}$

b) Konfigurasi Software
i) Xampp
ii) Web browser menggunakan Google Chrome atau Mozilla Firefox

\section{B. Permodelan Sistem}

Permodelan sistem yang digunakan dalam penelitian ini adalah sebagai berikut.

\section{Use Case Diagram}

Pemodelan use case diagram pada sistem informasi layanan kesehatan puskesmas bululawang kabupaten Malang digambarkan pada Gambar 2 


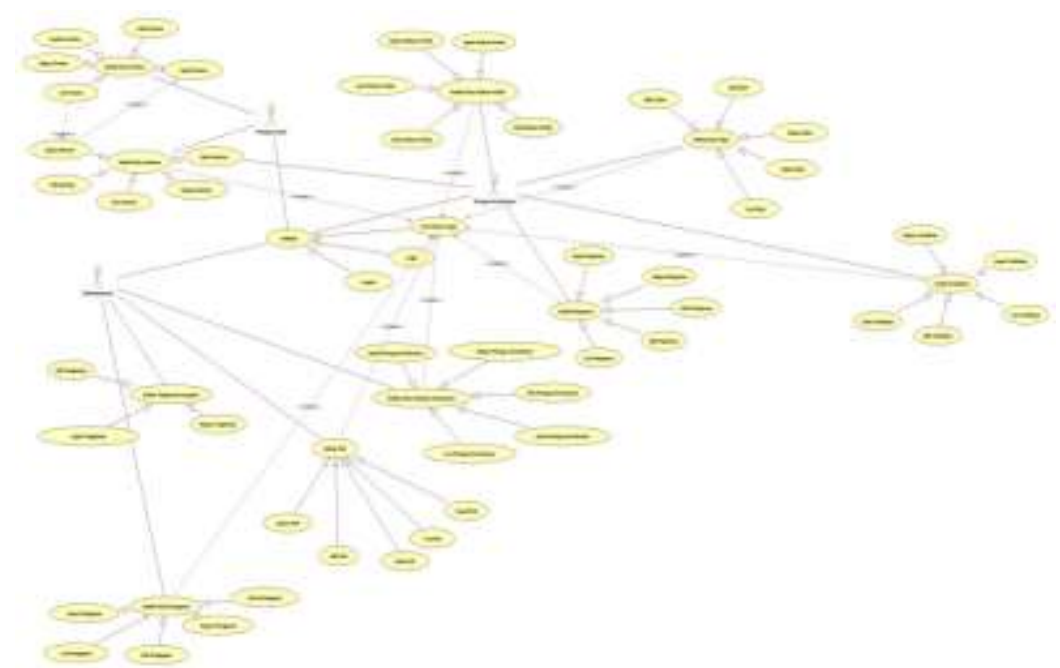

Gambar 2. Use Case Diagram Sistem Layanan Kesehatan

Pada Gambar 2 tersebut dapat dijabarkan Identifikasi Actor yang menggunakan Sistem, yaitu sebagai berikut :

TABEL 1

IDENTIFIKASI ACTOR

\begin{tabular}{cll}
\hline No & \multicolumn{1}{c}{ Nama Actor } & \multicolumn{1}{c}{ Job Desk } \\
\hline 1 & Petugas Loket & $\begin{array}{l}\text { mendata pasien dan mencatat rekam medis yang } \\
\text { ingin berobat dan memberikan nomor antrian } \\
\text { kepada pengunjung yang ingin berobat }\end{array}$ \\
& & $\begin{array}{l}\text { untuk memeriksa pasien dan memberikan resep } \\
\text { obat kepada apotik } \\
\text { bertanggung jawab dalam master data berupa } \\
\text { tambah, edit data, mencetak dan verifikasi data } \\
\text { login }\end{array}$ \\
\hline
\end{tabular}

Sedangkan, untuk kegiatan yang berada di Use Case adalah sebagai berikut.

TABEL 2.

IDENTIFIKASI USE CASE

\begin{tabular}{|c|c|c|}
\hline No & Nama Kegiatan & Keterangan \\
\hline 1 & Login & $\begin{array}{l}\text { Proses yang dilakukan oleh seluruh actor yang } \\
\text { terlibat dalam sistem ini seperti petugas loket, } \\
\text { petugas kesehatan, dan admin untuk masuk } \\
\text { kedalam sistem dengan memasukkan username } \\
\text { dan password. }\end{array}$ \\
\hline 2 & Kelola Data Pasien & $\begin{array}{l}\text { Proses yang di lakukan oleh petugas loket untuk } \\
\text { melihat data pasien, input data, update data, } \\
\text { hapus data, mencari data pasien. }\end{array}$ \\
\hline 3 & Kelola Data Antrian & $\begin{array}{l}\text { Proses ini akan di lakukan oleh petugas loket } \\
\text { untuk input data antrian, edit, mencari data } \\
\text { antrian, menghapus data antrian, dan melihat data } \\
\text { antrian. Data antrian juga bisa di lihat oleh } \\
\text { petugas kesehatan untuk bisa mengetahui jumlah } \\
\text { antrian pasien di loket. }\end{array}$ \\
\hline 4 & Kelola Data Pengguna & $\begin{array}{l}\text { Proses yang dilakukan oleh admin untuk } \\
\text { menambah, mengedit, mencari dan menghapus } \\
\text { data user. }\end{array}$ \\
\hline 5 & Kelola Data Poli & $\begin{array}{l}\text { Proses ini hanya bisa diakses oleh bagian } \\
\text { administrator, karena admin adalah sumber dari }\end{array}$ \\
\hline
\end{tabular}




\begin{tabular}{|c|c|c|}
\hline & & $\begin{array}{l}\text { master data. Di dalam kelola poli admin bisa } \\
\text { menghapus, menambah, mengedit dan melakukan } \\
\text { pencarian data poli }\end{array}$ \\
\hline 6 & Kelola Data Petugas Kesehatan & $\begin{array}{l}\text { Proses yang dilakukukan oleh admin ini bertujuan } \\
\text { untuk menghapus, menambah, mengedit dan } \\
\text { melakukan pencarian data petugas kesehatan }\end{array}$ \\
\hline 7 & Kelola Data Rekam Medis & $\begin{array}{l}\text { Proses ini dilakukan oleh petugas kesehatan untuk } \\
\text { dapat melihat, menghapus, menambahakan, } \\
\text { merubah, dan mencari data rekam medis. }\end{array}$ \\
\hline
\end{tabular}

\section{Squence Diagram}

\section{a. Squence Diagram Pendaftaran Pasien}

Berikut ini merupakan squence diagram dari Kelola Petugas Kesehatan menjelaskan proses input, edit, hapus data pasien yang di lakukan oleh Petugas Loket.

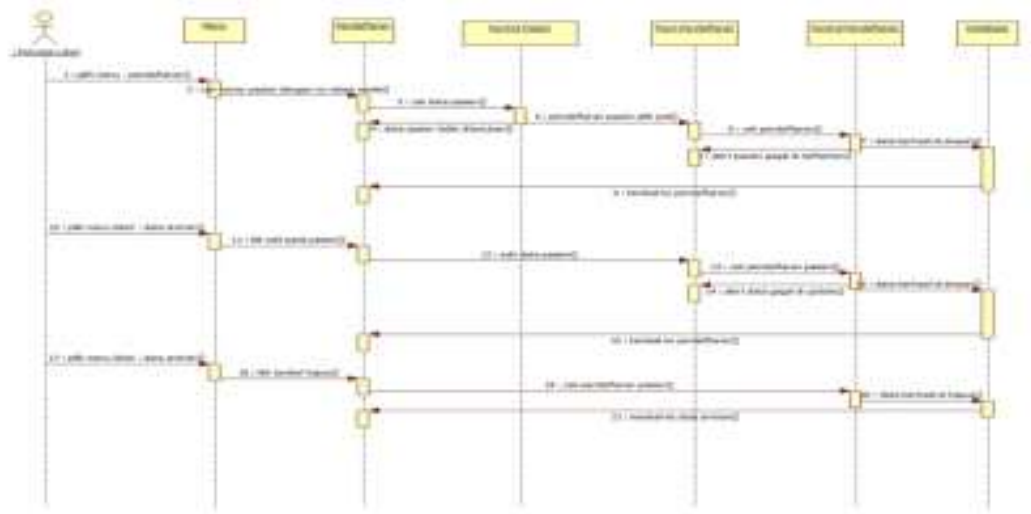

Gambar 3. Squence Diagram Pendaftaran Pasien

\section{b. Squence Diagram Data Rekam Medis}

Gambar 4 menjelaskan menjelaskan proses input, edit data rekam medis yang di lakukan oleh Petugas kesehatan.

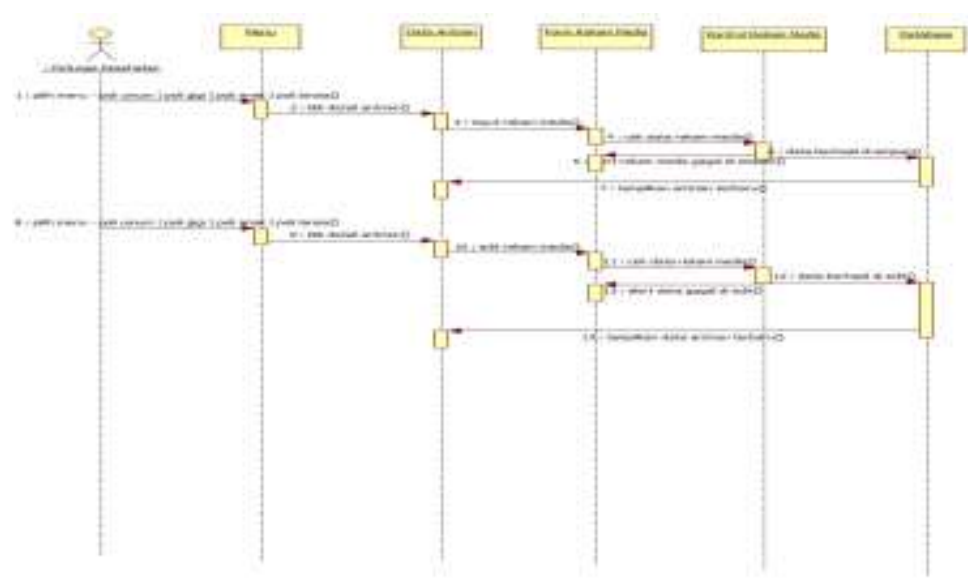

Gambar 4. Squence Diagram Data Rekam Medis

\section{Class Diagram}

Class diagram dibawah ini menggambarkan hubungan sistem informasi layanan kesehatan puskesmas bululawang kabupaten malang. Sistem ini tampak pada Gambar 5. 


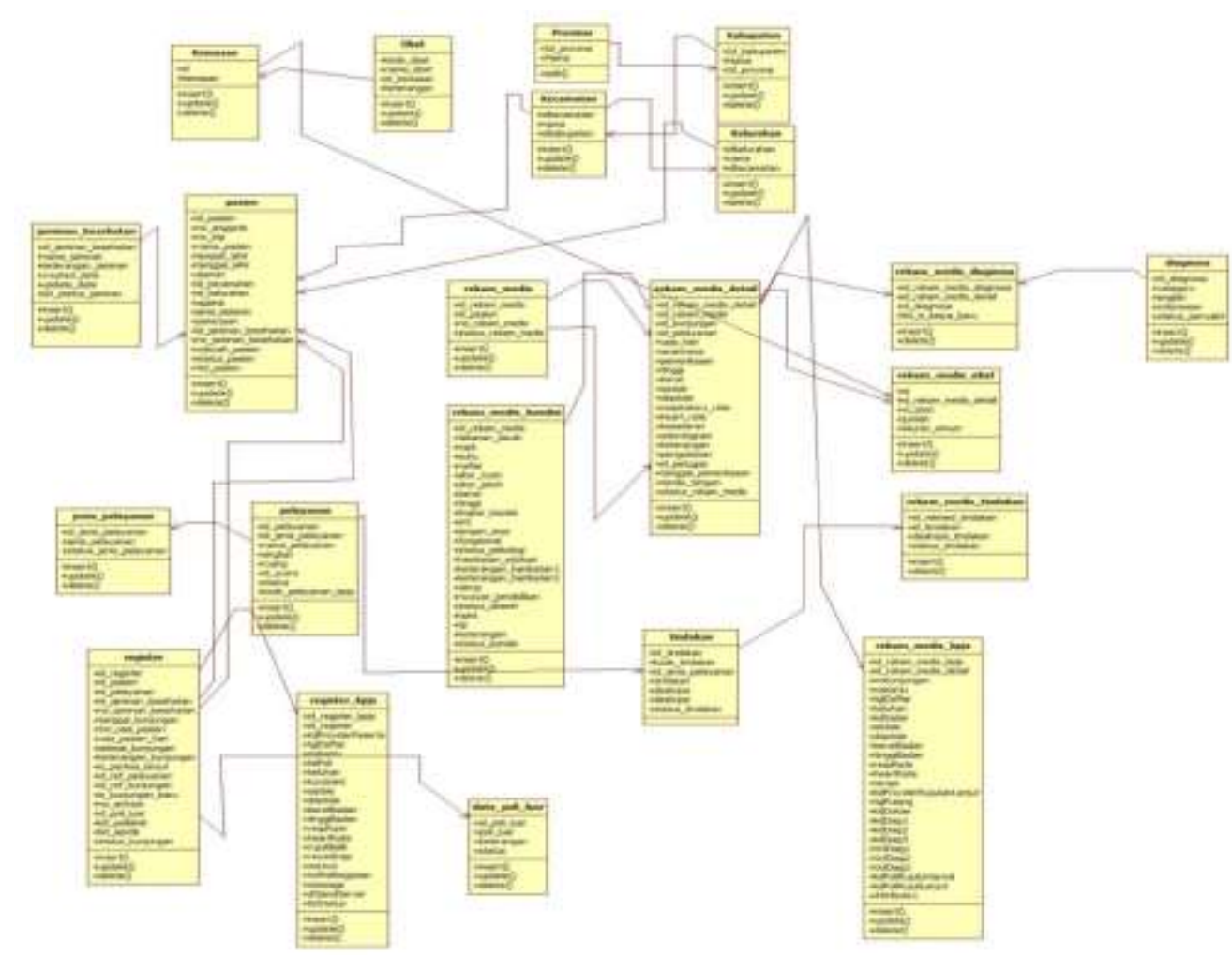

Gambar 5. Class Diagram Layanan Kesehatan

\section{A. Pengujian Fungsionalitas}

\section{Hasil Dan Pembahasan}

Pengujian fungsionalitas sistem dengan menggunakan metode blackbox testing yaitu metode pengujian dengan cara menguji masukan yang terdapat pada sistem yang dibangun. Tahap awal dalam pengujian sistem adalah pembuatan suatu rencana pengujian sistem yang menjabarkan fungsi dari sistem yang akan diuji. Rencana pengujian sistem pada penelitian ini disajikan pada Tabel 3.

TABEL 3.

Tabel Rencana Pengujian Sistem

\begin{tabular}{cll}
\hline No & \multicolumn{1}{c}{ Item Uji } & \multicolumn{1}{c}{ Detail Pengujian } \\
\hline 1 & Login & Username, Password, \\
2 & Pendaftaran Pasien & Tambah data, ubah, dan hapus \\
3 & Rekam Medis & Pencarian Data Rekam Medis \\
\hline
\end{tabular}

\section{Login}

Pengujian Login digunakan untuk membatasi hak akses/otoritas pada sistem. Apabila seluruh form login diisi dengan benar, maka pengguna dapat masuk ke sistem sesuai otoritasnya, akan tetapi jika seluruh form tidak diisikan dengan benar maka pengguna ditolak oleh sistem untuk masuk ke sistem. Pengujian login ditunjukkan pada Tabel 4.

TABEL 4.

Pengujian Login

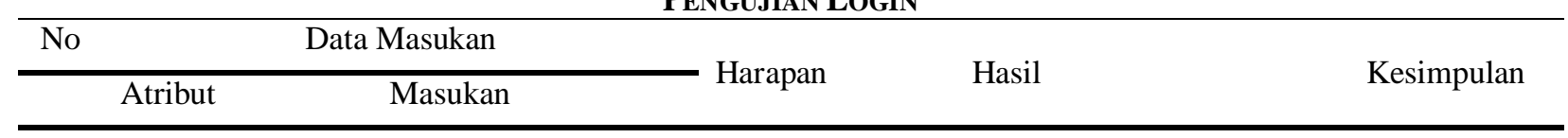




\begin{tabular}{clllll}
\hline 1 & Username & <salah> & Login Gagal & Login Gagal, Anda & Pengujian \\
& Password & Password12345 & & Tidak terdaftar! & Sukses, \\
2 & Username & Admin & Login Gagal & Login Gagal, Password & Pengujian \\
& Password & <salah> & & Anda Tidak Cocok! & Sukses \\
& Password & <Kosong> & & & \\
& Password & <Kosong> & & & \\
3 & Username & Admin & Login Sukses, & Masuk Halaman Utama & Pengujian \\
& Password & Password12345 & Masuk Halaman & & Sukses \\
& & Utama & & \\
\hline
\end{tabular}

\section{Pengujian Pendaftaran Pasien}

Pengujian form pendaftaran pasien yang digunakan untuk melakukan pendaftaran bagi pasien yang belum terdaftar di puskesmas. Pengujian pengajuan proposal ditunjukkan pada Tabel 5 berikut.

TABEL 5.

Pengujian Pendaftaran Pasien

\begin{tabular}{|c|c|c|c|c|c|}
\hline \multirow[t]{2}{*}{ No } & & ta Masukan & \multirow{2}{*}{ Harapan } & \multirow{2}{*}{ Hasil } & \multirow{2}{*}{ Kesimpulan } \\
\hline & Atribut & Masukan & & & \\
\hline \multirow[t]{16}{*}{1} & No Anggota & $\langle$ kosong $>$ & & & \\
\hline & Nama Pasien & $<$ kosong $>$ & & & \\
\hline & No. KTP/NIK & $\langle$ kosong $>$ & & & \\
\hline & Jenis Kelamin & $<$ kosong $>$ & & & \\
\hline & Agama & $<$ kosong $>$ & & & \\
\hline & Tempat Lahir & $<$ kosong $>$ & & & \\
\hline & Tanggal Lahir & $<$ kosong $>$ & Input Gagal & Lengkapi & Pengujian \\
\hline & No Handphone & $<$ kosong $>$ & & Isian! & Sukses \\
\hline & Pekerjaan & $<$ kosong $>$ & & & \\
\hline & Jaminan Kesehatan & $\langle$ kosong $>$ & & & \\
\hline & Alamat & $<$ kosong $>$ & & & \\
\hline & Kecamatan & $<$ kosong $>$ & & & \\
\hline & Kelurahan & $<$ kosong $>$ & & & \\
\hline & Wilayah Pasien & $\langle$ kosong $>$ & & & \\
\hline & Status Pasien & $<$ kosong $>$ & & & \\
\hline & & $\langle$ kosong $>$ & & & \\
\hline \multirow[t]{15}{*}{2} & No Anggota & $<$ kosong $>$ & & & \\
\hline & Nama Pasien & Hasan & & & \\
\hline & No. KTP/NIK & 023456376537738 & & & \\
\hline & Jenis Kelamin & $\mathrm{L}$ & & & \\
\hline & Agama & Islam & & & \\
\hline & Tempat Lahir & Malang & & & \\
\hline & Tanggal Lahir & 22 Januari 1994 & & & \\
\hline & No Handphone & 0865435467 & Input & Lengkapi & Pengujian \\
\hline & Pekerjaan & Programmer & Gagal! & Isian! & Sukses \\
\hline & Jaminan Kesehatan & BPJS & & & \\
\hline & Alamat & Jl. Raya Krebet & & & \\
\hline & Kecamatan & Bululawang & & & \\
\hline & Kelurahan & Bululawang & & & \\
\hline & Wilayah Pasien & Bululawang & & & \\
\hline & Status Pasien & Dalam Wilayah Aktif & & & \\
\hline \multirow[t]{8}{*}{3} & No Anggota & 00001 & & & \\
\hline & Nama Pasien & Hasan & & & \\
\hline & No. KTP/NIK & 023456376537738 & & & \\
\hline & Jenis Kelamin & $\mathrm{L}$ & & & \\
\hline & Agama & Islam & & & \\
\hline & Tempat Lahir & Malang & Input & Pasien & Pengujian \\
\hline & Tanggal Lahir & 22 Januari 1994 & Sukses & Terdaftar & Sukses \\
\hline & No Handphone & 0865435467 & & & \\
\hline
\end{tabular}




\begin{tabular}{ll}
\hline Pekerjaan & Programmer \\
Jaminan Kesehatan & BPJS \\
Alamat & Jl. Raya Krebet \\
Kecamatan & Bululawang \\
Kelurahan & Bululawang \\
Wilayah Pasien & Bululawang \\
Status Pasien & Dalam Wilayah Aktif \\
\hline
\end{tabular}

\section{Pengujian Rekam Medis}

Pengujian Rekam Medis ini digunakan untuk meminimalisir kesalahan pada saat pengelolaan data yang akan di masukkan. Pengelolaan halaman ini hanya di otoritaskan kepada semua petugas kesehatan sedangkan admin akan membagi menu-menu yang akan di tampilkan/diotorisasikan kepada user. Pengujian rekam medis ditunjukkan pada Tabel 6.

TABEL 6.

Pengujian Rekam Medis

\begin{tabular}{|c|c|c|c|c|c|}
\hline \multirow{2}{*}{ No } & \multicolumn{2}{|c|}{ Data Masukan } & \multirow[b]{2}{*}{ Harapan } & \multirow{2}{*}{ Hasil } & \multirow[b]{2}{*}{ Kesimpulan } \\
\hline & Atribut & Masukan & & & \\
\hline 1 & $\begin{array}{l}\text { Nama Pasien } \\
\text { No rekam Medis }\end{array}$ & $\begin{array}{l}\text { <kosong }> \\
\text { <kosong> }\end{array}$ & Input Gagal & $\begin{array}{l}\text { Lengkapi Fill } \\
\text { terlebih dahulu }\end{array}$ & Pengujian Sukses \\
\hline 2 & $\begin{array}{l}\text { Nama Pasien } \\
\text { No rekam Medis }\end{array}$ & $\begin{array}{l}\langle\text { kosong }> \\
00245675345\end{array}$ & Input Gagal & $\begin{array}{ll}\text { Lengkapi } & \text { Fill } \\
\text { terlebih dahulu } & \end{array}$ & Pengujian Sukses \\
\hline 3 & $\begin{array}{l}\text { Nama Pasien } \\
\text { No rekam Medis }\end{array}$ & $\begin{array}{l}\text { Hasan } \\
00245675345\end{array}$ & Input Berhasil & $\begin{array}{l}\text { Data Berhasil Di } \\
\text { Simpan }\end{array}$ & Pengujian Sukses \\
\hline
\end{tabular}

\section{B. Pengujian Kinerja Sistem}

Pengujian dengan metode pengukuran waktu yaitu metode pengujian dengan cara menguji lama proses sistem dijalankan. Tahap awal dalam pengujian sistem adalah pembuatan suatu rencana pengujian sistem yang menjabarkan fungsi dari sistem yang akan diuji. Rencana pengujian sistem pada penelitian ini disajikan pada Tabel 7 berikut ini.

TABEL 7.

Tabel Rencana Pengujian

\begin{tabular}{llll}
\hline No & \multicolumn{1}{c}{ Item Uji } & \multicolumn{1}{c}{ Detail Pengujian } & \multicolumn{1}{c}{ Jenis Pengujian } \\
\hline 1 & Proses Pendaftaran Pasien & Proses Pendaftaran Pasien & Lama Waktu Proses \\
2 & Proses Pencarian Data Rekam & Proses Pencarian Data Rekam Medis & Lama Waktu Proses \\
& Medis Pasien & Pasien & Lama Waktu Proses \\
\hline
\end{tabular}

\section{Hasil Pengujian Fungsionalitas}

Setiap halaman pada sistem telah diuji, dengan cara memasukkan data pada setiap form input yang ada, baik berbeda karakter maupun nilai. Hasil yang keluar akan dicocokkan dengan hasil yang diharapkan. Berdasarkan pengujian sistem yang telah dilakukan, berikut adalah tampilan dari hasil pengujian. 


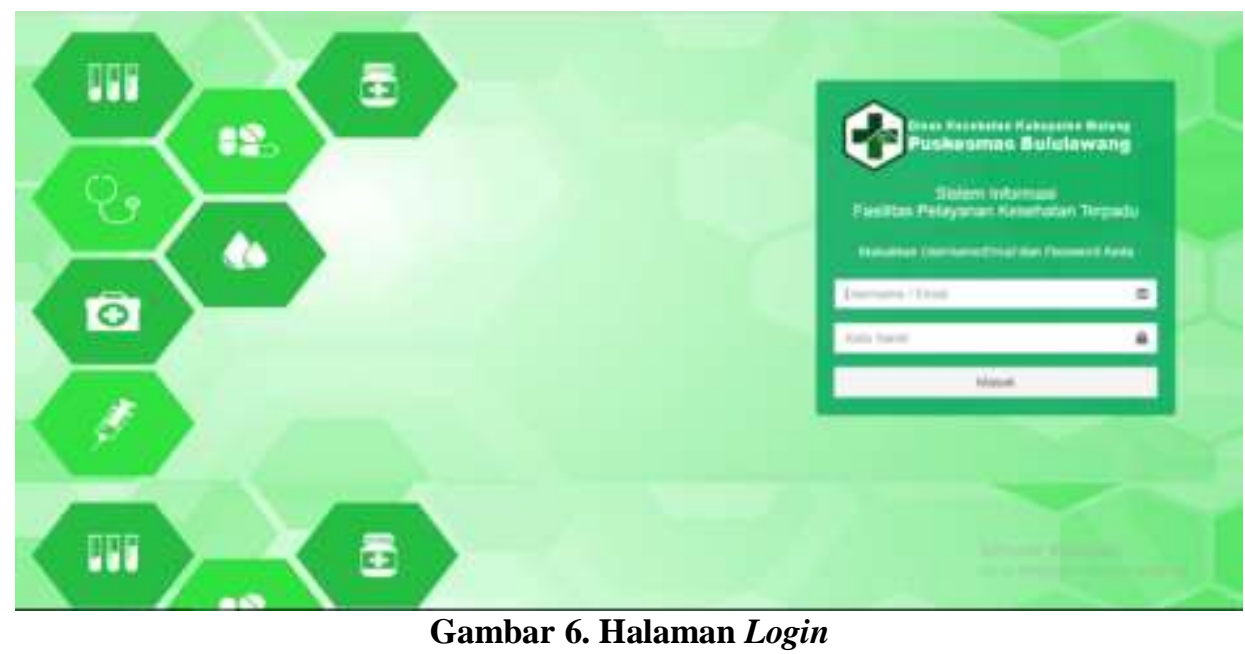

Halaman login gagal jika seluruh form tidak diisi dengan benar, maka akan muncul peringatan yang memicu kegagalan tersebut. Berikut tatap muka login gagal seperti pada Gambar 7.

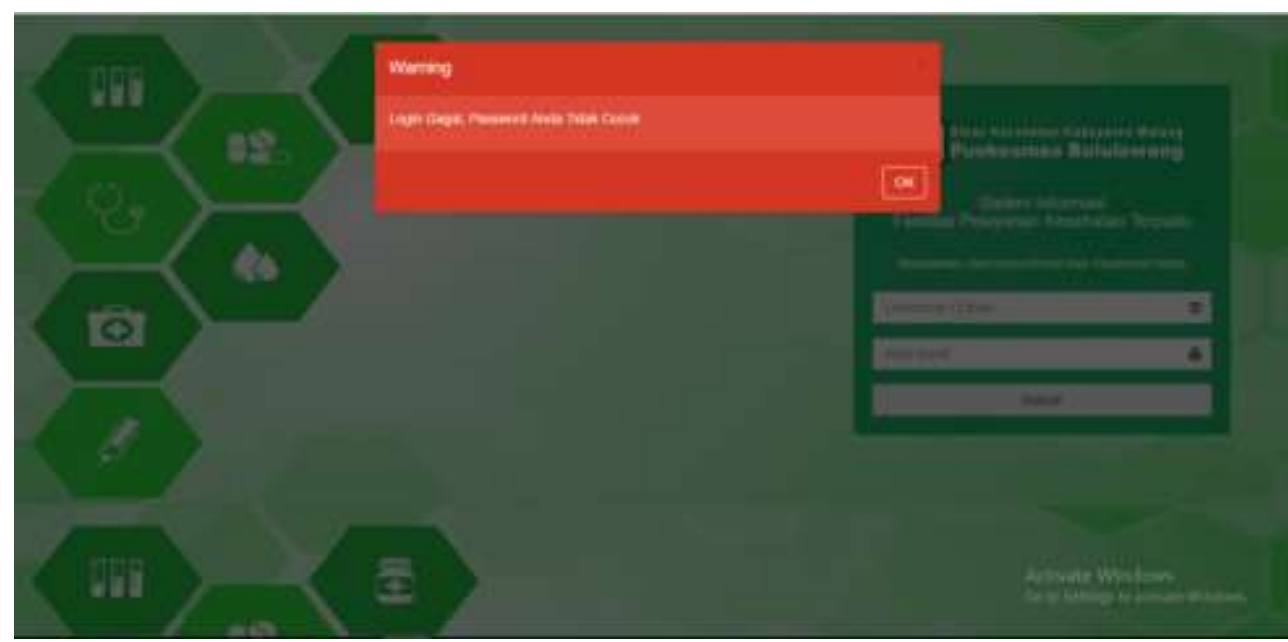

Gambar 7. Login Gagal

Halaman pendaftaran pasien tidak akan bisa tersimpan jika data tersebut tidak diisi dengan lengkap. Halaman ini hanya bisa diisi oleh petugas loket puskesmas Bululawang. Berikut tatap muka form pendaftaran pasien pada Gambar 8

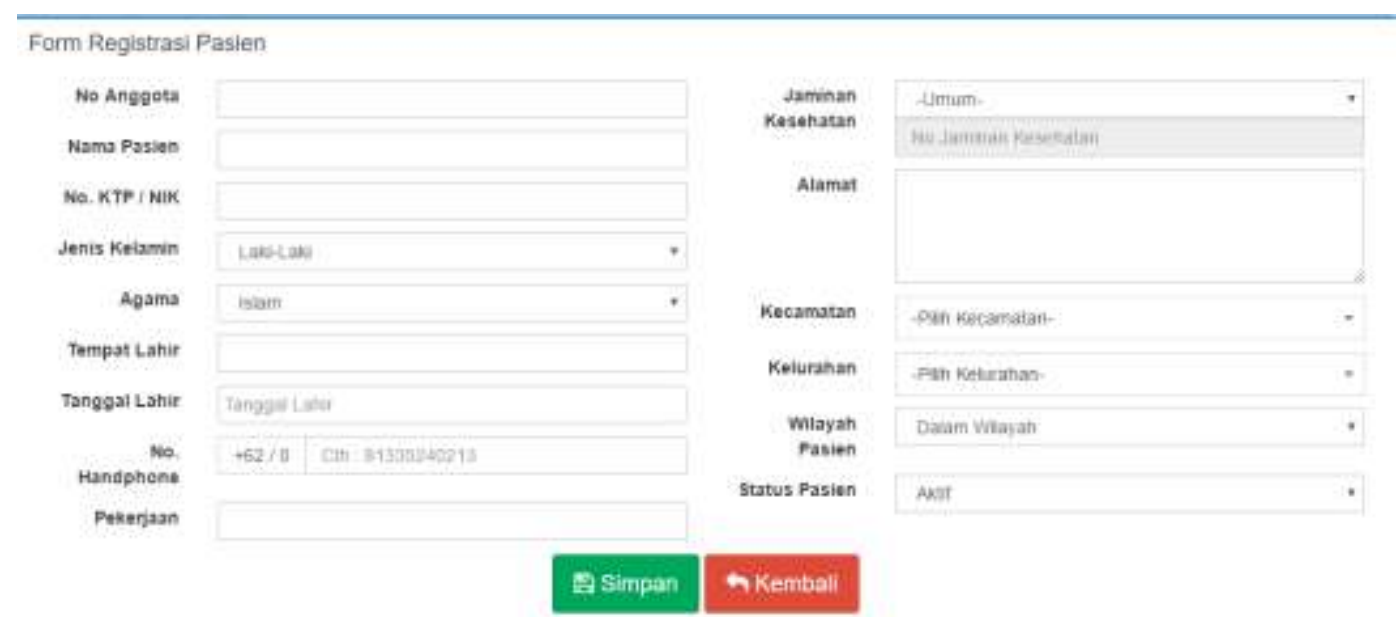

Gambar 8. Form Registrasi

Antivirus: Jurnal Ilmiah dan Teknik Informatika, Mei 2018, Vol. 12, No. 1 
Halaman Data Antrian akan terisi otomatis apabila petugas loket memasukkan data pasien tersebut kedalam daftar kunjungan. Berikut tatap muka halaman data antrian pasien pada Gambar 9.

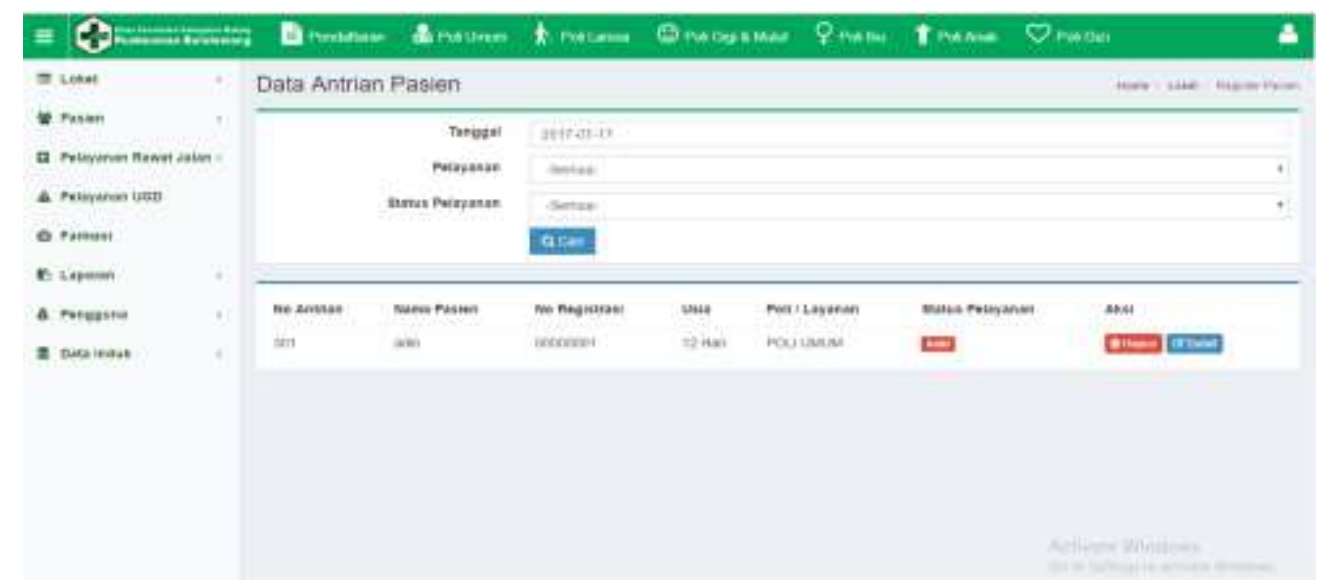

Gambar 9. Data Antrian Pasien

Halaman Pasien akan otomatis terisi apabila input data pasien dilakukan. Berikut tatap muka menu data pasien pada Gambar 10.

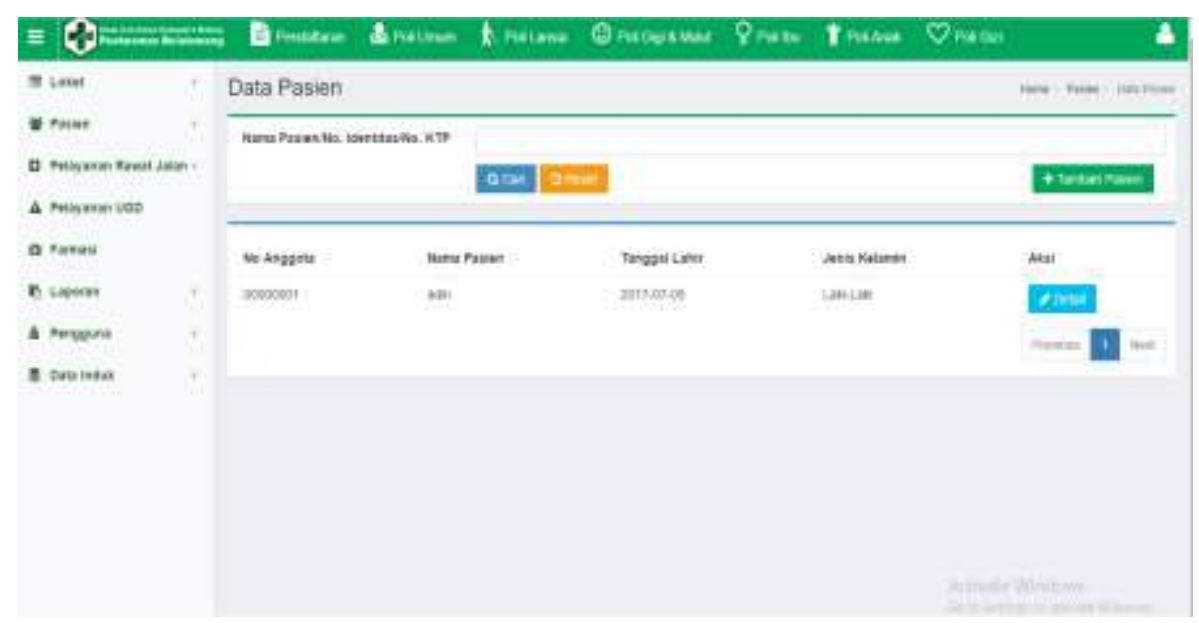

Gambar 10. Data Pasien

Pada halaman pasien ada menu rekam medis, menu tersebut akan terisi sebuah data pasien apabila petugas kesehatan telah memasukkan riwayat rekam medis pasien tersebut. Berikut tatap muka menu rekam medis pada Gambar 10. 


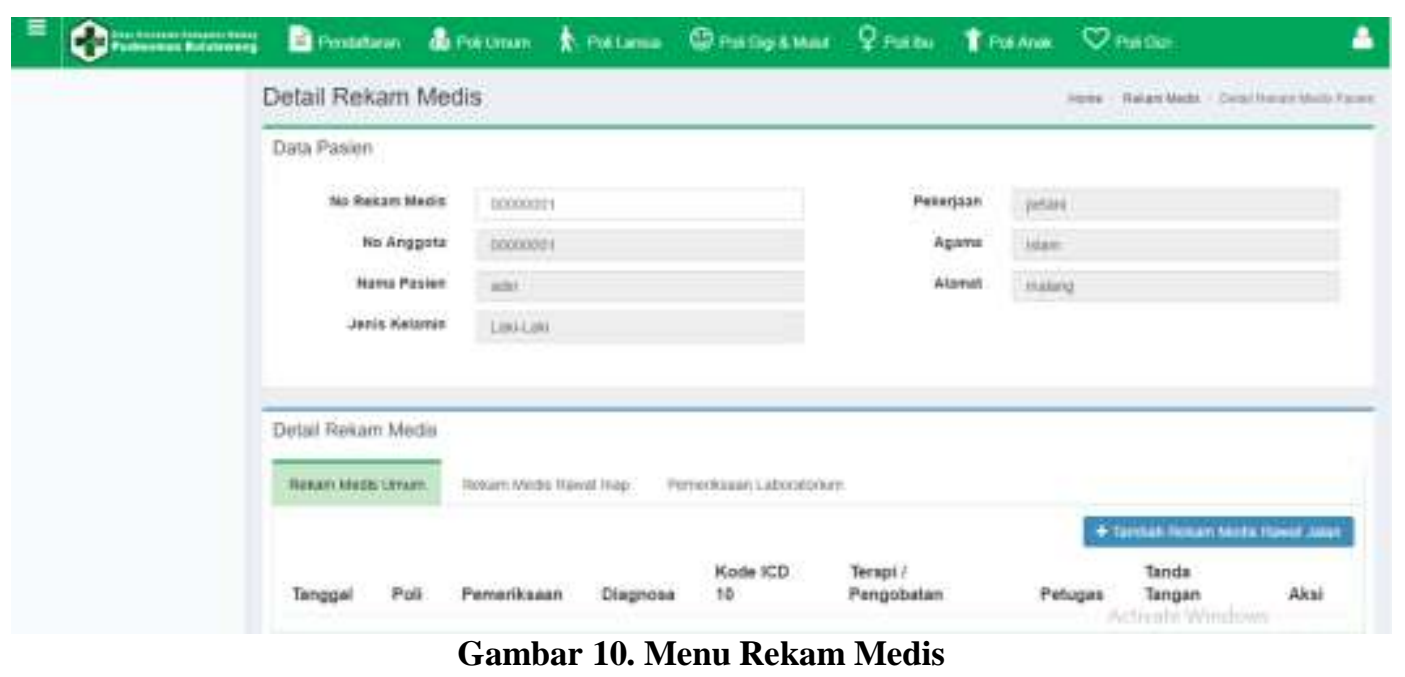

Menu Rekam Medis Harian berfungsi untuk merekap seluruh data pasien pada hari tersebut. Berikut tatap muka menu rekam medis harian pada Gambar 11

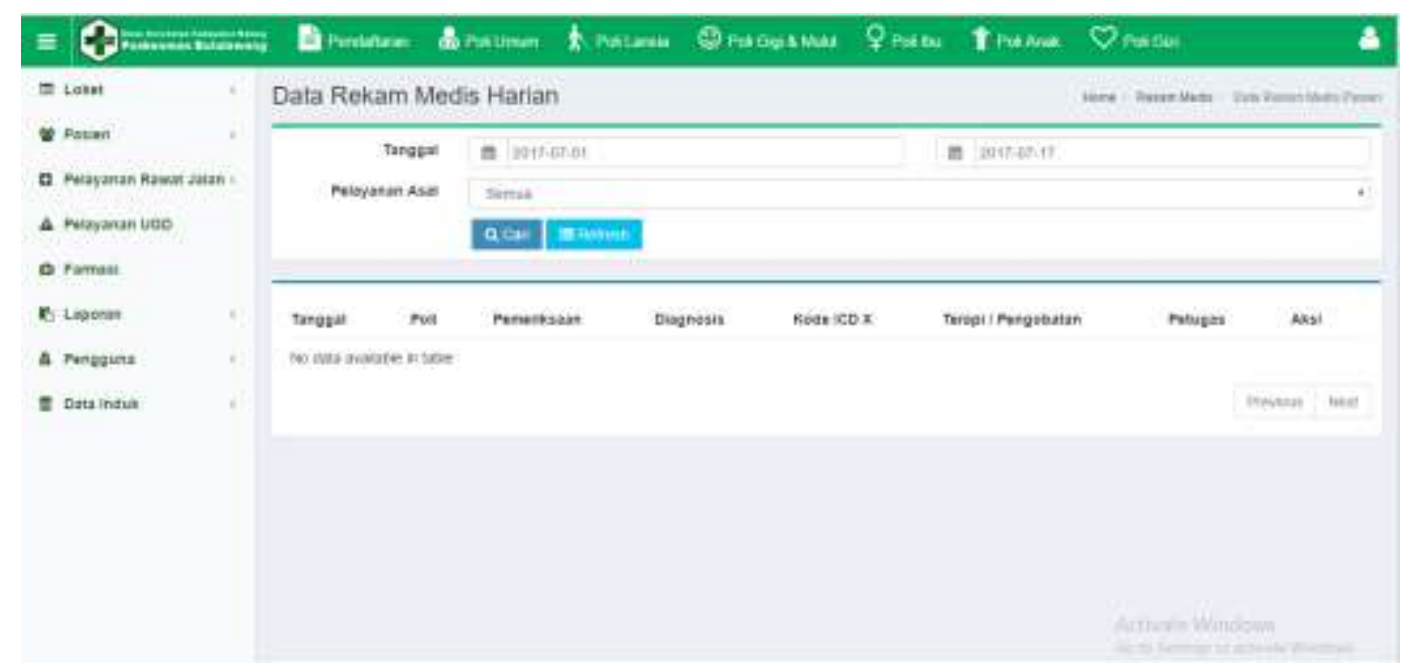

Gambar 11. Menu Rekam Medis Harian

Menu Rekapitulasi Pelaporan berfungsi untuk merekap seluruh data pasien pada hari tertentu sesuai dengan permintaan pembuatan laporan 


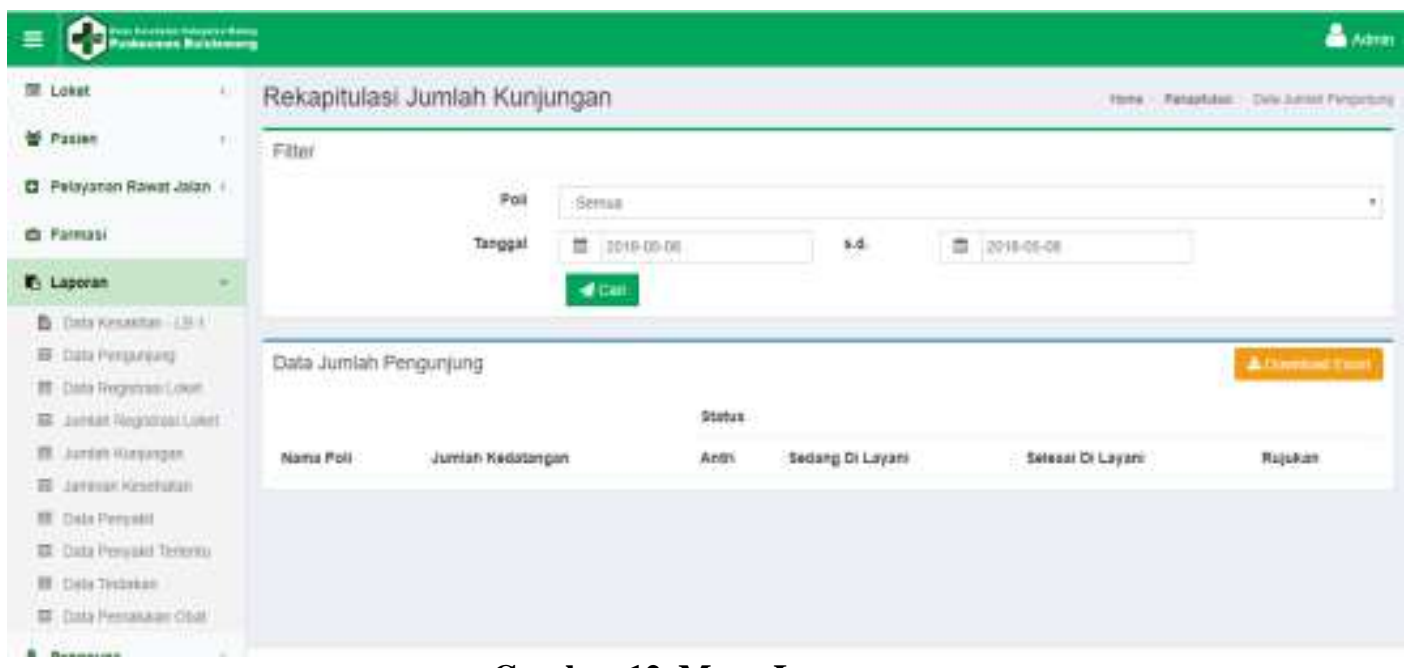

Gambar 12. Menu Laporan

\section{Hasil Pengujian Pelayanan}

Pengujian Pendaftaran Pasien dilakukan dengan cara menghitung lama proses pengerjaan dapat dilihat dalam Tabel 8 berikut.

TABEL 8.

Hasil Pengujian KinerJa Sistem

\begin{tabular}{|c|c|c|c|c|c|}
\hline No & Item Uji & Detail Pengujian & $\begin{array}{c}\text { Pengujian Sistem } \\
\text { Lama }\end{array}$ & $\begin{array}{c}\text { Pengujian Sistem } \\
\text { Baru }\end{array}$ & $\begin{array}{r}\text { Prosentase } \\
\text { Kenaikan }\end{array}$ \\
\hline 1 & $\begin{array}{l}\text { Proses Pendaftaran } \\
\text { Pasien }\end{array}$ & $\begin{array}{l}\text { Proses Pendaftaran } \\
\text { Pasien }\end{array}$ & 40 menit & 5 menit & $87,5 \%$ \\
\hline 2 & $\begin{array}{l}\text { Proses Pencarian } \\
\text { Data Rekam Medis } \\
\text { Pasien }\end{array}$ & $\begin{array}{l}\text { Proses Pencarian Data } \\
\text { Rekam Medis Pasien }\end{array}$ & 30 menit & 4 detik & $99,7 \%$ \\
\hline 3 & $\begin{array}{l}\text { Proses Pembuatan } \\
\text { Laporan }\end{array}$ & $\begin{array}{l}\text { Proses Pembuatan } \\
\text { Laporan Medis }\end{array}$ & 7 hari & 5 menit & $97,02 \%$ \\
\hline
\end{tabular}

\section{A. Kesimpulan}

\section{KESIMPULAN DAN SARAN}

Berdasarkan hasil analisa dan pengembangan aplikasi sistem informasi layanan kesehatan puskesmas bululawang yang telah dilakukan, maka dapat diambil kesimpulan sebagai berikut:

1. Pencatatan dan akses data pasien, pengolahan data rekam medis, dan akses riwayat rekam medis pasien dapat diakses dengan mudah oleh petugas kesehatan.

2. Pengolahan data rekam medis yang lebih mudah dapat membantu dalam pembuatan laporan puskesmas yang lebih cepat.

3. Adanya peningkatan pelayanan dari segi waktu yang lebih cepat dengan kenaikan yang signifikan yaitu sebesar 87,5 \% untuk proses pendaftaran, 99,7 \% untuk proses pencarian Data Rekam Medis, 97,02 \% untuk proses pembuatan Laporan Medis

4. Aplikasi sistem informasi Puskesmas dapat meningkatkan kualitas pelayanan kesehatan masyarakat oleh petugas kesehatan kepada pasien.

\section{B. Saran}

Adapun saran yang dapat disampaikan untuk peningkatan dan pengembangan Sistem informasi layanan kesehatan puskesmas bululawang adalah sebagai berikut: 
1. Untuk pengembangan selanjutnya Sistem informasi yang dikembangkan pada pelayanan rawat inap dan inventory apotik agar dapat berintegrasi dengan sistem informasi rawat jalan yang telah berjalan.

2. Sistem informasi dapat dikembangkan dan ditambahkan dengan sistem pemutakhiran data setiap tahunnya agar aplikasi dapat berjalan dengan baik.

\section{Daftar Pustaka}

Akhmad Syukron, N. H. 2015. Perancangan Sistem Informasi Rawat Jalan Berbasis Web Pada Puskesmas Winong. Bianglala Informatika, Vol 3. No.1.

Ernawati, B. E. 2014. Pembangunan Sistem Informasi Puskesmas Pembantu Desa Nglaran. Indonesian Journal of Network \& Security, Vol 3. No. 3.

Hakim, L. 2010. Membangun WEB Berbasis PHP Dengan Framework. Yogyakarta: Lokomedia. Kadir, A. 2014. Pengenalan Sistem Informasi Edisi Revisi. Yogyakarta: Andi.

Peraturan Menteri Kesehatan Republik Indonesia No.269/MENKES/PER/III/2008 Tentang Rekam Medis

Pradikta Andrianto, A. N. 2017. Sistem Informasi Pelayanan Kesehatan Berbasis Web. Prosiding Seminar Nasional Komputer dan Informatika (SENASKI), ISBN: 978-602-60250-1-2.

Satzinger, J. B. 201). System Analysis and Desaign with the Unified Process. United States: Cengage Learning, Course Technology.

UU Praktik Kedokteran Pasal 46 ayat 1, T. 2. (n.d.). n.d.

\section{Riwayat Penulis}

Jurnal ini ditulis oleh penulis pertama Eka Yuniar, S.Kom., MMSI. Penulis lahir dan besar di Kota Malang, pada tanggal 10 Juni 1990, Penulis menyelesaikan studi S1 di STMIK PPKIA Pradnya Paramita jurusan Sistem Informasi yang lulus pada Tahun 2014, serta melanjutkan Studi S2 di Universitas Gunadarma jurusan Manajemen Sistem Informasi dengan mengambil konsentrasi Perangkat Lunak Sistem Informas (PLSI). Penulis menyelesaikan Studi S2 pada Tahun 2016. Saat ini penulis aktif sebagai staff pengajar di STMIK PPKIA Pradnya Paramita sejak Desember 2016. 